\title{
A New Trophic State Index for Lagoons
}

\author{
Mukesh Gupta ${ }^{1,2}$ \\ ${ }^{1}$ Earth Sciences and Hydrology Division, Marine and Earth Sciences Group, Remote Sensing Applications and \\ Image Processing Area, Space Applications Centre, Indian Space Research Organization, Ahmedabad, Gujarat 380 015, India \\ ${ }^{2}$ Centre for Earth Observation Science, Department of Environment and Geography, Clayton H. Riddell Faculty of Environment, \\ Earth, and Resources, University of Manitoba, 463 Wallace Building, Winnipeg, MB, Canada R3T 2N2 \\ Correspondence should be addressed to Mukesh Gupta; guptm@yahoo.com
}

Received 27 December 2013; Revised 27 January 2014; Accepted 28 January 2014; Published 9 March 2014

Academic Editor: Wen-Cheng Liu

Copyright (C) 2014 Mukesh Gupta. This is an open access article distributed under the Creative Commons Attribution License, which permits unrestricted use, distribution, and reproduction in any medium, provided the original work is properly cited.

This paper proposes a new nitrogen-based trophic state index (TSI) for the estimation of status of eutrophication in a lagoon system. Nitrite-nitrogen $\left(\mathrm{NO}_{2}-\mathrm{N}\right)$ is preferable because of its greater abundance in Chilika lagoon and its relation to other criteria of trophic state, for example, chlorophyll-a (Chl- $a$ ) and Secchi disk depth (SDD). Nitrite is preferable over nitrate because the former decreases the fluorescence and affects photosynthesis, thereby controlling primary production. This paper also computes TSI using Chl- $a$ and SDD. The three parameters account for the biological, chemical, and physical characteristics of the lagoon. It will be possible to estimate the TSI of freshwater and brackish water lagoons and other water bodies using the new expressions taking into consideration the spatial and temporal variability in the dataset. Depending on the data availability, alternative TSI (Chl- $a$ ) and TSI (SDD) can account for the biological and physical contributions to eutrophication. The estimated TSI can account for Chl- $a$ and $\mathrm{NO}_{2}-\mathrm{N}$ up to $322.18 \mathrm{mg} \mathrm{m}^{-3}$ and $61.99 \mu \mathrm{g} \mathrm{L}^{-1}$, respectively. The TSI based on these three parameters can serve as a complimentary and predictive tool for lagoon management and field programs to monitor the health of a lagoon.

\section{Introduction}

It is much easier to convey to the public the status and nature of a lagoon through an index, which provides the scientific accord of eutrophication and character of the lagoon. The monitoring of water quality, especially in the inland water bodies, aquifers, lakes, reservoirs, and lagoons, is important as it helps with the management of the eutrophication and productivity of the water body. Carlson [1] made early attempts to define an index, termed trophic state index (TSI), which could tell about the trophic status and nature of the lakes. Based on this trophic index, further classification of eutrophication of a lake into oligotrophic, mesotrophic, and eutrophic was possible. Because of water pollution and contamination of inland and coastal water bodies, it has become important to develop methods to determine such index of eutrophication of coastal lagoons that provides better spatial and temporal coverage.

Carlson [1] presented the trophic condition on a $0-100$ scale; however, the author reported three different TSI values, that is, total phosphorus (TP), chlorophyll- $a$ (Chl- $a$ ), and
Secchi disk transparency depth (SDD) [2]. To eliminate this confusion, Osgood [3] suggested using differences in the indices to assess the water quality in lakes. The basis of the development of an index of trophic state depends on the characteristic features and peculiarity of eutrophication. Different from Carlson's and others' approaches, O'Boyle et al. [4] have recently suggested $\mathrm{pH}$ - and dissolved oxygenbased index of status of eutrophication. Chalar et al. [5] report a completely different TSI based on benthic invertebrates, which is little dependent on environment variables. The variability and dominance of specific eutrophication parameters in different lakes hold the key to using a suitable index because different lakes may have different sources of nutrients, depth, and size. So far, there is no universally applicable trophic index reported which could adequately predict the productive character of a coastal lagoon.

However, many trophic scales, water quality indices, and measures of an assessment of water quality and trophic status of lakes, estuaries, and marine coastal areas are abundant in the literature. For example, Vollenweider et al. [6] proposed a new trophic index (TRIX) based on Chl- $a$, oxygen saturation, 


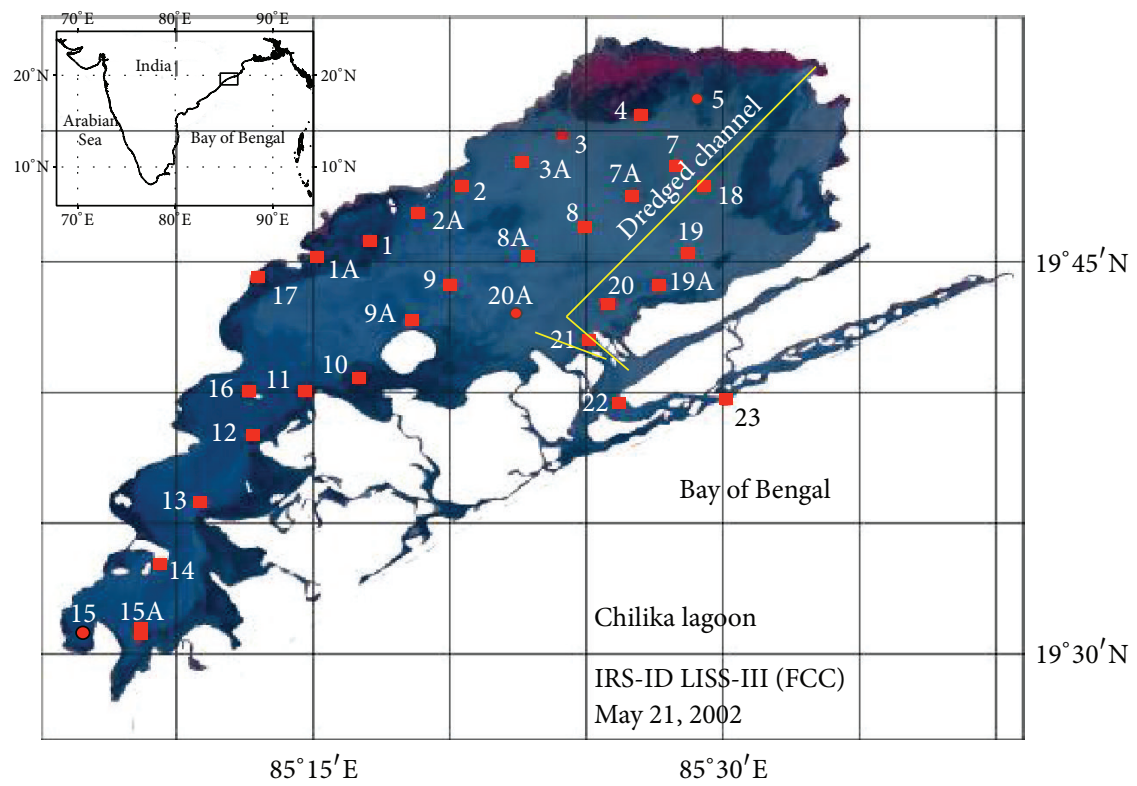

FIGURE 1: A map of Chilika lagoon, at Odisha coast, India. The background satellite imagery is IRS-1D LISS-III (FCC-false color composite) of May 21, 2002.

mineral, total nitrogen, and phosphorus for coastal marine waters. TRIX is scaled from 0 to 10 , which covers a wide range of trophic conditions. Analogously, a turbidity index (TRBIX) serves as a complimentary water quality index. TRIX and analogous other indices are most useful for saline coastal marine waters but are not well suited for a brackish water lagoon. Padisák et al. [7] have developed an assemblage index, $Q$, to assess ecological status of lake types established by the Water Framework Directive (WFD). Q varies from 0 to 5 and provides a 5 -grade qualification as required by WFD. But $Q$ is primarily a phytoplankton assemblage index that neglects water quality parameters. OSPAR, Oslo/Paris convention (for the Protection of the Marine Environment of the North-East Atlantic), has adopted COMPP (Comprehensive Procedure) for the identification of eutrophication status of OSPAR Maritime Area [8]. Although, OSPAR COMPP provides a holistic procedure for trophic state assessment, it does not set any thresholds for the trophic status indicator variables (e.g., Chl- $a$, water clarity, etc.), and there are no differential weightings across indicators. Bricker et al. [9] have suggested an analogous integrated methodology for the Assessment of Estuarine Trophic Status (ASSETS) for eutrophication status of estuaries and coastal areas [9]. It considers a whole suite of nutrients and water quality parameters for a detailed assessment but suffers from lengthy and computation demanding procedure for trophic assessment. However, it has a limitation to only estuaries and coastal waters. An index that is easy to implement, a first-hand approach for a quicker assessment of trophic status of a brackish water lagoon, is still a requirement.

The most common estimates of TSI have their basis on various in situ water quality data collected in the lake [1]. The spatial and temporal changes that occur in the lake constrain these estimates. Wezernak et al. [10] reported a method using Chl- $a$ and SDD as parameters for the determination of TSI. Thiemann and Kaufmann [11] determined TSI based on Chl- $a$ estimated using field spectrometer data for lakes in Germany. Walker Jr. [12] suggested a TSI based on depletion of dissolved oxygen from in situ measurements as a measure of status of water quality of lakes. Analogous to Carlson's [1] trophic indices, Kratzer and Brezonik [13] estimated TSI for total nitrogen based on in situ measurements for various lakes in Florida, USA. Nitrite-nitrogen $\left(\mathrm{NO}_{2}-\mathrm{N}\right)$ is an important element in a lagoon system because it is present in plant tissues, compost, manure, soil, food, fertilizer, mineral, water, and yellow substances. Literature on a TSI primarily based on nitrogen (nitrite or nitrate or ammonia) is rare. This paper does not use ammonia to compute TSI as it nitrifies into nitrite by bacterial oxidation [4]. This paper presents a new detailed model of TSI based on $\mathrm{NO}_{2}-\mathrm{N}$ with intercomparison to TSI based on Chl- $a$, and SDD for Chilika lagoon's eutrophication status.

\section{Study Area and Sampling Data}

The study area lies between $19^{\circ} 28^{\prime}-19^{\circ} 54^{\prime} \mathrm{N}$ and $85^{\circ} 05^{\prime}-$ $85^{\circ} 38^{\prime} \mathrm{E}$ in the coastal regions of the state of Odisha, India (Figure 1). Eastern Ghats hills surround the eastern and western margins of the lagoon. There are 52 small rivulets in the north that drain fresh water into the lagoon, main rivers being Daya and Bhargavi Rivers, the distributaries of Mahanadi River [14]. The Bay of Bengal seawater enters the lagoon through a mouth midway along the east coast length of the lagoon.

Chilika lagoon, situated on the east coast of India in the state of Odisha, is the second largest brackish water lagoon 
in the world [15]. Ramsar Convention designated it as a Wetland of International Importance, since 1 October 1981. The pear-shaped lagoon sprawls about $64 \mathrm{~km}$ in length NESW and about $5-18 \mathrm{~km}$ in width from S-N covering an area of $1165-906 \mathrm{~km}^{2}$ during the monsoon and summer, respectively. Chilika lagoon is a shallow water body with the deepest point of $\sim 3 \mathrm{~m}$ in the southern end and the shallowest point of $\sim$ $60 \mathrm{~cm}$ in the northern end. It opens in the Bay of Bengal through an artificially opened mouth approximately $200 \mathrm{~m}$ wide. This new artificial mouth was opened in 2007 by cutting and dredging the sand spit, to increase the eutrophication and protect wild life habitat, which were declining due to decreasing salinity after the closure of northern opening into the Bay of Bengal $[14,16]$.

Water sample data collection campaign occurred during 2001-2003 at 27 different locations, evenly distributed in the lagoon to cover the entire lagoon area (Figure 1). Stations 15, $15 \mathrm{~A}, 14,13,12,16,11,10$, and 17 in the southern sector were comparatively deeper. Stations in the central sector were 1 , $1 \mathrm{~A}, 2,2 \mathrm{~A}, 8 \mathrm{~A}, 9,9 \mathrm{~A}, 20 \mathrm{~A}$, and 21 . The northern sector stations $3,3 \mathrm{~A}, 4,7,7 \mathrm{~A}, 8,19,19 \mathrm{~A}$, and 20 were shallow, characterized by very high suspended sediment concentration. The sample analysis, that is, filtering, weighing, and so forth assisted in retrieving Chl- $a, \mathrm{NO}_{2}-\mathrm{N}$, and SDD values. The samples were filtered through GF/C Whatman filter paper for the analysis of Chl- $a$. $\mathrm{NO}_{2}-\mathrm{N}$ data were analyzed according to the method described by Strickland and Parsons [17]. Generally, Chilika lagoon has lower values of nitrite except during monsoon when there are higher nitrite values resulting from release by decomposed freshwater weeds into the water column [18]. Table 1 provides the range and general statistics of Chl- $a$, $\mathrm{NO}_{2}-\mathrm{N}$, and SDD.

\section{Materials and Methods}

The use of many variables responsible for the eutrophication of lagoon may question the selection of two-three variables for determining the trophic state of the lagoon. However, the evaluation of only a few variables is the basis of the need for a TSI that can provide the trophic status of the lagoon and to avoid the large computations involving multiparameter statistical analysis to arrive at an indicator of trophic state of the lagoon. A TSI should have its basis on only a few variables that one can easily measure and analyze with optimum effort.

In the present analysis, Chl- $a, \mathrm{NO}_{2}-\mathrm{N}$, and SDD have been chosen as the potential candidates for estimating a TSI which can cover a substantial range of concentrations of each of the three parameters and is applicable to any brackish water lake, lagoon, inland water body, and reservoir. One can easily measure and understand the SDD, because it is dependent on direct human vision. SDD and Chl- $a$ are representatives of the optical scattering and absorption in the lagoon waters. The underwater light availability in the lagoon controls the general growth/health of the microorganisms, biomass, flora, and fauna. Nitrogen is one of the major nutrient components of the food chain of a lagoon, rather to say, it lies at the base of food web and provides food for all living organisms in a lagoon.
TABLE 1: The range and general statistics of in situ data used in Model A computation for TSI.

\begin{tabular}{lcccc}
\hline Parameter & Minimum & Maximum & Mean & Standard deviation \\
\hline $\mathrm{SDD}(\mathrm{cm})$ & 10 & 200 & 56 & 32 \\
$\mathrm{Chl}-a\left(\mathrm{mg} \mathrm{m}^{-3}\right)$ & 0.09 & 48.53 & 4.92 & 5.57 \\
$\mathrm{NO}_{2}-\mathrm{N}\left(\mu \mathrm{g} \mathrm{L}^{-1}\right)$ & 0.08 & 3.65 & 0.62 & 0.68 \\
\hline
\end{tabular}

3.1. Reasons for Choosing Nitrite for TSI Estimation. $\mathrm{NO}_{2}-\mathrm{N}$ is preferable for TSI estimation because of its greater abundance in a trophic system and its relation to the other criteria of trophic state such as Chl- $a$ and SDD. The presence of nitrite in biomass rich water decreases fluorescence thus affecting the Chl- $a$ and photosynthesis [19], and thereby regulating primary production of the lagoon. A Chl- $a$ based trophic index is likely to underestimate the trophic state of the lagoon in the presence of nitrite. A nitrite-based index can overcome this problem. Nitrate is not preferable, though it is more stable than nitrite, because nitrate does not have any influence on the Chl- $a$; thus, it does not affect the fluorescence and photosynthesis [19]. Secondly, SDD-based TSI is likely to be confused with water quality index; however, the nutrientbased index should serve as a better indicator of the trophic status in a lagoon. Finally, the computed TSI values undergo a validation at each station in the lagoon to check if the computed TSI values are consistent with the observations in the lagoon.

3.2. Model A. This model computes a TSI based on the Carlson's model [1]. The relationship among three parameters, that is, Chl- $a, \mathrm{NO}_{2}-\mathrm{N}$, and SDD, is nonlinear and is computed as follows (no transformation of the data values into logarithmic and so forth was performed, only the nontransformed actual data values have been used):

$$
\begin{aligned}
& \frac{1}{\mathrm{SDD}}=1.4479+0.7763 \mathrm{NO}_{2}-\mathrm{N} \quad\left(n=60 ; R^{2}=0.7753\right) \\
& \frac{1}{\mathrm{SDD}}=0.216+0.8771 \mathrm{Chl}-a \quad\left(n=60 ; R^{2}=0.7761\right)
\end{aligned}
$$

where, $n$ sample points constitute the data for regression; $R^{2}$ is the coefficient of determination. The model computes corresponding TSI values for Chl- $a, \mathrm{NO}_{2}-\mathrm{N}$, and SDD. These are as follows:

$$
\begin{gathered}
\text { TSI }(\text { SDD })=10\left[6+\frac{\ln (1 / \mathrm{SDD})}{\ln 2}\right], \\
\operatorname{TSI}\left(\mathrm{NO}_{2}-\mathrm{N}\right)=10\left[6+\frac{\ln \left(1.4479+0.7763 \mathrm{NO}_{2}-\mathrm{N}\right)}{\ln 2}\right], \\
\operatorname{TSI}(\mathrm{Chl}-a)=10\left[6+\frac{\ln (0.2160+0.8771 \mathrm{Chl}-a)}{\ln 2}\right] .
\end{gathered}
$$

The model underestimates the computed values of Chl- $a$ and $\mathrm{NO}_{2}-\mathrm{N}$ in the absence of upper limits of the SDD. 
3.3. Model B. This model is a slight modification of Model A. Defining the maximum limit of SDD and computing the TSI for Chl- $a$ and $\mathrm{NO}_{2}-\mathrm{N}$ from the empirical equations construct this model

$$
b^{a}=\mathrm{SDD}_{\max } .
$$

It is safe to consider $\mathrm{SDD}_{\max }$ as $200 \mathrm{~cm}$ for Chilika lagoon. Let us consider

$$
\operatorname{TSI}(\mathrm{SDD})=10\left[a+\frac{\ln (1 / \mathrm{SDD})}{\ln b}\right] .
$$

Solving (1) and (4), we get $a=1.5475$ and $b=1.5650$ :

$$
\text { TSI }(S D D)=10\left[1.5475+\frac{\ln (1 / S D D)}{\ln 1.565}\right] \text {, }
$$

$$
\operatorname{TSI}\left(\mathrm{NO}_{2}-\mathrm{N}\right)
$$

$$
=10\left[1.5475+\frac{\ln \left(1.4479+0.7763 \mathrm{NO}_{2}-\mathrm{N}\right)}{\ln 1.565}\right] \text {, }
$$

TSI (Chl-a)

$$
=10\left[1.5475+\frac{\ln (0.2160+0.8771 \mathrm{Chl}-a)}{\ln 1.565}\right] .
$$

3.4. Model C. This model is a slight modification of Model B. An improved nonlinear relationship among Chl- $a, \mathrm{NO}_{2}-\mathrm{N}$, and SDD is obtained for a limited range of each parameter as follows:

$$
\begin{gathered}
\frac{1}{\mathrm{SDD}}=1.135+0.6926 \mathrm{NO}_{2}-\mathrm{N} \quad\left(n=61 ; R^{2}=0.8455\right), \\
\frac{1}{\mathrm{SDD}}=1.0907+0.1334 \text { Chl }-a \quad\left(n=60 ; R^{2}=0.8487\right), \\
0.09 \leq \text { Chl }-a \leq 20.00, \quad 25 \leq \mathrm{SDD} \leq 120 .
\end{gathered}
$$

One can compute TSI (SDD) using the formula given in (5),

$$
\mathrm{TSI}(\mathrm{SDD})=10\left[1.5475+\frac{\ln (1 / \mathrm{SDD})}{\ln 1.565}\right],
$$

Substituting (8) and (9) into (11), respectively, we get TSI $\left(\mathrm{NO}_{2}-\mathrm{N}\right)$ and TSI $(\mathrm{Chl}-a)$,

$$
\begin{gathered}
\operatorname{TSI}\left(\mathrm{NO}_{2}-\mathrm{N}\right)=10\left[1.5475+\frac{\ln \left(1.135+0.6926 \mathrm{NO}_{2}-\mathrm{N}\right)}{\ln 1.565}\right], \\
\operatorname{TSI}(\mathrm{Chl}-a)=10\left[1.5475+\frac{\ln (1.0907+0.1334 \mathrm{Chl}-a)}{\ln 1.565}\right] .
\end{gathered}
$$

\section{Results and Discussion}

A large amount of data collected over three-year span during monsoon, summer, and postmonsoon provides a basis of the results in this study. Thus, the data contain large variability required for formulating an ameliorated TSI for a brackish water lagoon.

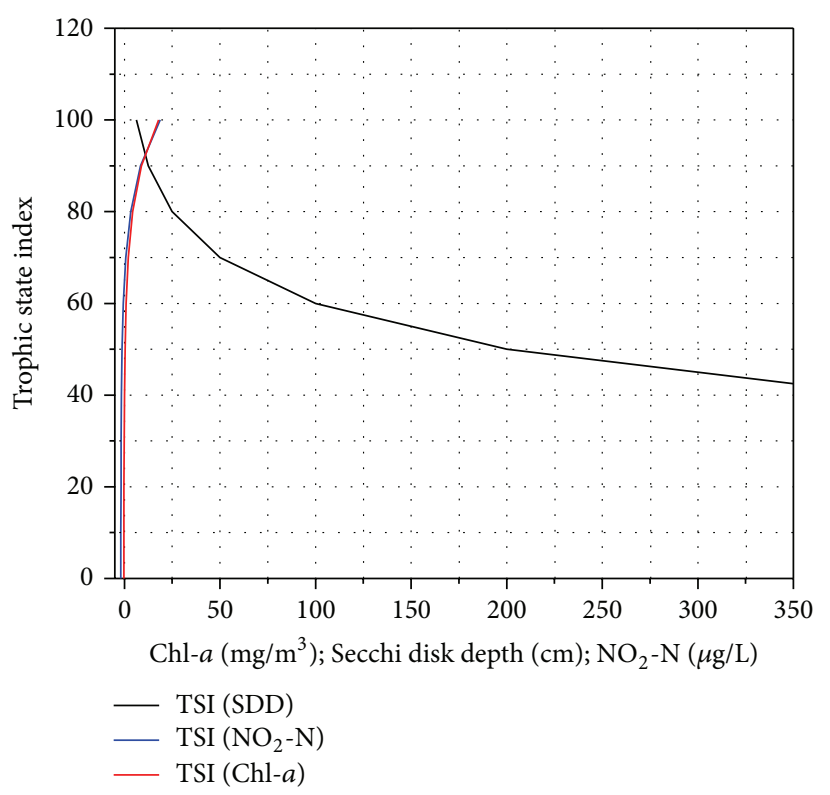

FIGURE 2: TSI versus corresponding values of Chl- $a, \mathrm{NO}_{2}-\mathrm{N}$, and SDD computed using Model A. Most Chl- $a$ and $\mathrm{NO}_{2}-\mathrm{N}$ values are underestimated which fall below zero. Note that the SDD is openended.

4.1. Model A. Carlson's index [1] provides a basis for Model A taking the entire data set into consideration. The computed TSI values are underestimated by this model and produce negative numbers for Chl- $a$ and $\mathrm{NO}_{2}-\mathrm{N}$. Figure 2 shows a plot of three TSI computed for Chl- $a, \mathrm{NO}_{2}-\mathrm{N}$, and SDD using Model A. The variability in Chl- $a$ and $\mathrm{NO}_{2}-\mathrm{N}$ does not reflect in the computed TSI whereas SDD is open-ended. Tables 1 and 2 provide the corresponding data values. Model A is obviously not a good TSI estimator for the Chilika lagoon.

4.2. Model B. Here, the SDD has a limit of a maximum depth of $200 \mathrm{~cm}$ for Chilika lagoon. The choice of $\mathrm{SDD}_{\max }$ relies on the observational data in the lagoon. One can elucidate the physical significance of this limitation on SDD through the penetration of light into the lagoon waters. The light availability, in turn, controls the growth of organisms, hence, the eutrophication in the lagoon. There is a requirement of further modifications and regulations to arrive at a reasonable TSI, which consider the entire range of concentrations of Chl$a, \mathrm{NO}_{2}-\mathrm{N}$, and SDD from the surface to the $\mathrm{SDD}_{\text {max }}$ in the lagoon. This model produces substantial negative values of the computed Chl- $a$ and $\mathrm{NO}_{2}-\mathrm{N}$; thus, it is not suitable for a good TSI (Table 3 ).

Figure 3 shows the results of Model B. The computed TSI clearly elucidates the variability in Chl- $a$ and $\mathrm{NO}_{2}-\mathrm{N}$. However, Model B also underestimates $\mathrm{NO}_{2}-\mathrm{N}$ beyond $21 \mathrm{~cm}$ of SDD. This implies that the model considers only the surface concentration of $\mathrm{NO}_{2}-\mathrm{N}$ up to a depth of $21 \mathrm{~cm}$ (Table 3).

4.3. Model $C$. The intersected area among the three curves corresponding to Chl- $a, \mathrm{NO}_{2}-\mathrm{N}$, and SDD provides the most common TSI values in a typical lagoon 
TABLE 2: TSI and corresponding values of Chl- $a, \mathrm{NO}_{2}-\mathrm{N}$, and SDD computed using Model $\mathrm{A}$. It is noticeable that this model gives negative numbers (shown as "- " dash), which implies the nonapplicability of this model for Chl- $a$ concentrations less than $0.04 \mathrm{mg} \mathrm{m}^{-3}$ and $\mathrm{NO}_{2}-\mathrm{N}$ concentrations less than $0.71 \mu \mathrm{g} \mathrm{L}^{-1}$.

\begin{tabular}{|c|c|c|c|}
\hline TSI & SDD computed $(\mathrm{cm})$ & $\mathrm{NO}_{2}-\mathrm{N}$ computed $\left(\mu \mathrm{g} \mathrm{L}^{-1}\right)$ & Chl- $a$ computed $\left(\mathrm{mg} \mathrm{m}^{-3}\right)$ \\
\hline 0 & 6400 & - & - \\
\hline 10 & 3200 & - & - \\
\hline 20 & 1600 & - & - \\
\hline 30 & 800 & - & - \\
\hline 40 & 400 & - & 0.04 \\
\hline 50 & 200 & - & 0.32 \\
\hline 60 & 100 & - & 0.89 \\
\hline 70 & 50 & 0.71 & 2.03 \\
\hline 80 & 25 & 3.29 & 4.31 \\
\hline 90 & 12 & 8.44 & 8.88 \\
\hline 100 & 6 & 18.75 & 18.00 \\
\hline
\end{tabular}

TABLE 3: TSI and corresponding values of Chl- $a, \mathrm{NO}_{2}-\mathrm{N}$, and SDD computed using Model $\mathrm{B}$. It is noticeable that this model gives negative numbers (shown as "-" dash), which implies the nonapplicability of this model for $\mathrm{NO}_{2}-\mathrm{N}$ concentrations less than $0.13 \mu \mathrm{g} \mathrm{L}^{-1}$. Model $\mathrm{B}$ shows slight improvement over Model A; however, the values of computed indices are underestimated in this model.

\begin{tabular}{|c|c|c|c|}
\hline TSI & SDD computed $(\mathrm{cm})$ & $\mathrm{NO}_{2}-\mathrm{N}$ computed $\left(\mu \mathrm{g} \mathrm{L}^{-1}\right)$ & Chl- $a$ computed $\left(\mathrm{mg} \mathrm{m}^{-3}\right)$ \\
\hline 0 & 200 & - & 0.32 \\
\hline 10 & 128 & - & 0.65 \\
\hline 20 & 82 & - & 1.15 \\
\hline 30 & 52 & - & 1.94 \\
\hline 40 & 33 & - & 3.17 \\
\hline 50 & 21 & 0.13 & 5.11 \\
\hline 60 & 14 & 0.70 & 8.13 \\
\hline 70 & 9 & 1.28 & 12.86 \\
\hline 80 & 6 & 1.86 & 20.27 \\
\hline 90 & 4 & 2.44 & 31.86 \\
\hline 100 & 2 & 3.01 & 50.00 \\
\hline
\end{tabular}

(Figure 4). For instance, Figure 5 shows the observed TSI validated/computed using the Model $\mathrm{C}$ from the observed data from the Chilika lagoon [20]. Each data point represents a mean value taken over several observations at select locations within the lagoon during monsoon, postmonsoon, and summer periods. Note that the data ranges provided in the Table 1 account for the entire data at all stations to create statistics. The observed data cover a large seasonal variability, for example, monsoon, summer, and postmonsoon, and temporal variability from 2001 to 2003. The computed TSI values go through a validation at each station in the lagoon. The physically observed eutrophication state and the predicted TSI-based health status are in good agreement.

A limited range of Chl- $a$ varying between 0.09 and $20.00 \mathrm{mg} \mathrm{m}^{-3}$ and $\mathrm{NO}_{2}-\mathrm{N}$ between 0.41 and $1.07 \mu \mathrm{g} \mathrm{L}^{-1}$ enables computation of reasonable values of TSI that covers greater ranges of concentration of Chl- $a$ and $\mathrm{NO}_{2}-\mathrm{N}$ (Figure 4). The high values of Chl- $a$ and $\mathrm{NO}_{2}-\mathrm{N}$ signify higher TSI in contrast to high values of transparency signifying low TSI. The variability in Chl- $a$ and $\mathrm{NO}_{2}-\mathrm{N}$ is well accounted for by the computed TSI (Table 4).

The TSI provided in the Model $\mathrm{C}$ has many advantages over previous trophic indices. One can increase the scale of
TSI (0 to 100$)$ if the concentrations of observed Chl- $a$ or $\mathrm{NO}_{2}-\mathrm{N}$ are even higher. The used ranges of Chl- $a, \mathrm{NO}_{2}-$ $\mathrm{N}$, and SDD provide sufficient information to construct a generalized TSI, which is likely to provide better estimates of the status of eutrophication in a lagoon. These parameters fundamentally account for the availability of organisms (Chl-a), food (nitrogen and phosphorus), and light (SDD), which are typical requirements for a healthy lagoon. In addition, these three parameters provide the biological (Chla), chemical $\left(\mathrm{NO}_{2}-\mathrm{N}\right)$, and physical (SDD) grounds for establishing the trophic state. Each of the three TSI obtained plays a role in biological, chemical, and physical contribution to the general eutrophication in the lagoon. One should consider the necessary abatement of controlling parameters for inverting the results to achieve the required TSI according to a standard. For example, Chilika Development Authority opened a new artificial mouth to the Bay of Bengal to increase the salinity of the lagoon and to control the eutrophication in the lagoon [16].

4.4. Comparison with Other Indices. Several different indices, having their basis on various eutrophication parameters, are available in the literature since Carlson [1] (see Introduction). 


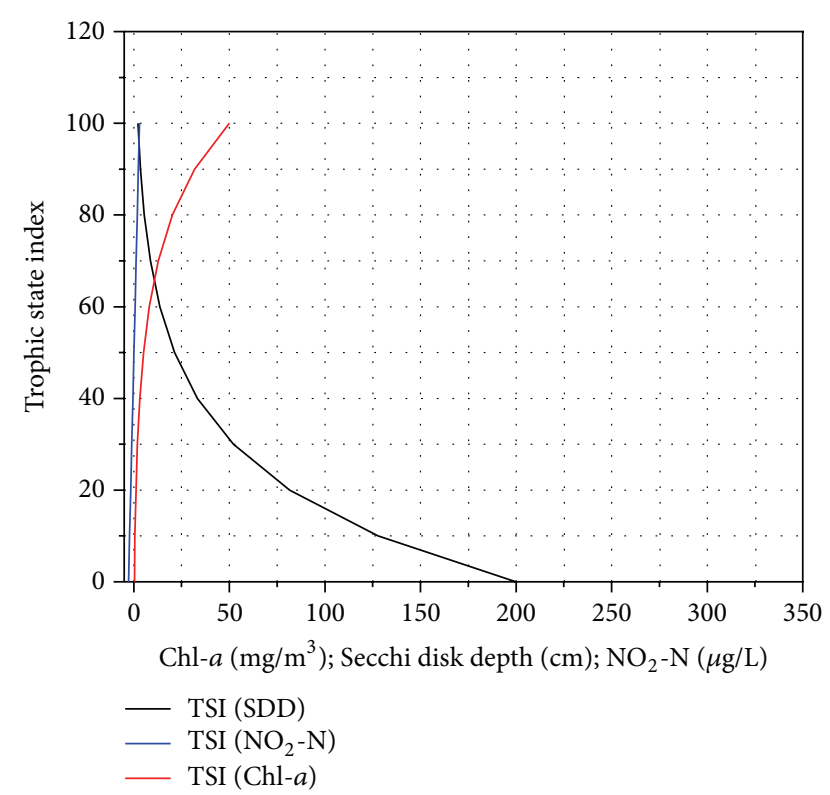

FIGURE 3: TSI versus corresponding values of Chl- $a, \mathrm{NO}_{2}-\mathrm{N}$, and $\mathrm{SDD}$ computed using Model $\mathrm{B}$. Some $\mathrm{NO}_{2}-\mathrm{N}$ values are underestimated which fall below zero. The SDD has a limit of $200 \mathrm{~cm}$.

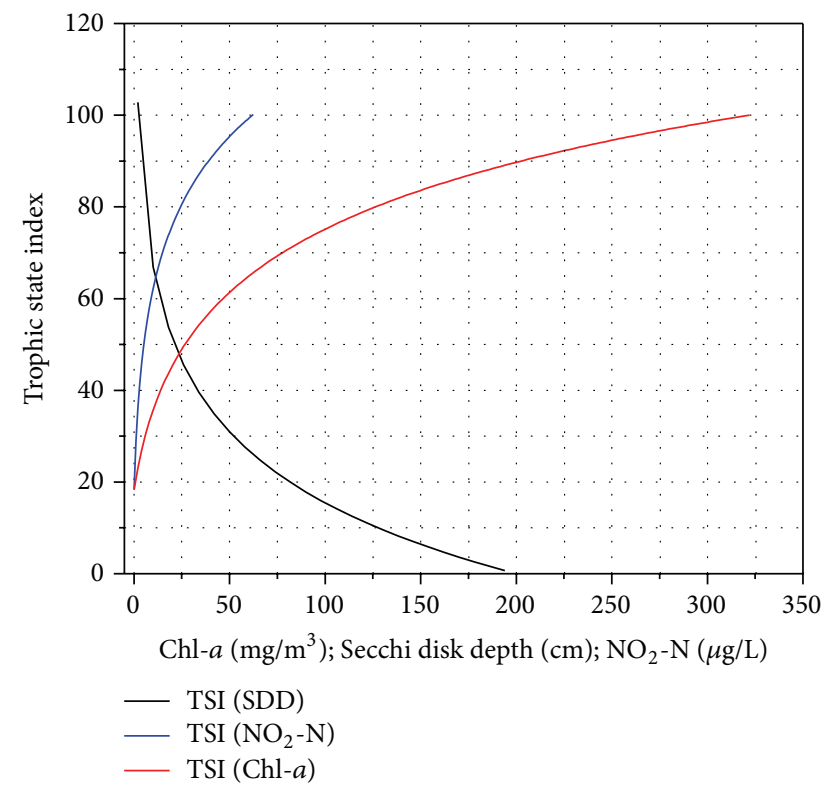

FIGURE 4: TSI versus corresponding values of Chl- $a, \mathrm{NO}_{2}-\mathrm{N}$, and SDD computed using Model C. None of parameters is underestimated.

Obtained TSI ranges are in comparison with that of a recent study by O'Boyle et al. [4] who used $\mathrm{pH}$ and dissolved oxygen as indicators of eutrophication in estuaries. Their study provides a range of $35.6-69.8 \mu \mathrm{g} \mathrm{L} \mathrm{L}^{-1}$ of Chl- $a$ corresponding to trophic index value range of $12.4-99.7$, respectively. In this paper, $0.09-48.53 \mathrm{mg} \mathrm{m}^{-3}$ of in situ Chl- $a$ values corresponds to TSI values between 0 and 100. This shows that the TSI in this study covers a large range of Chl- $a$ values that are not

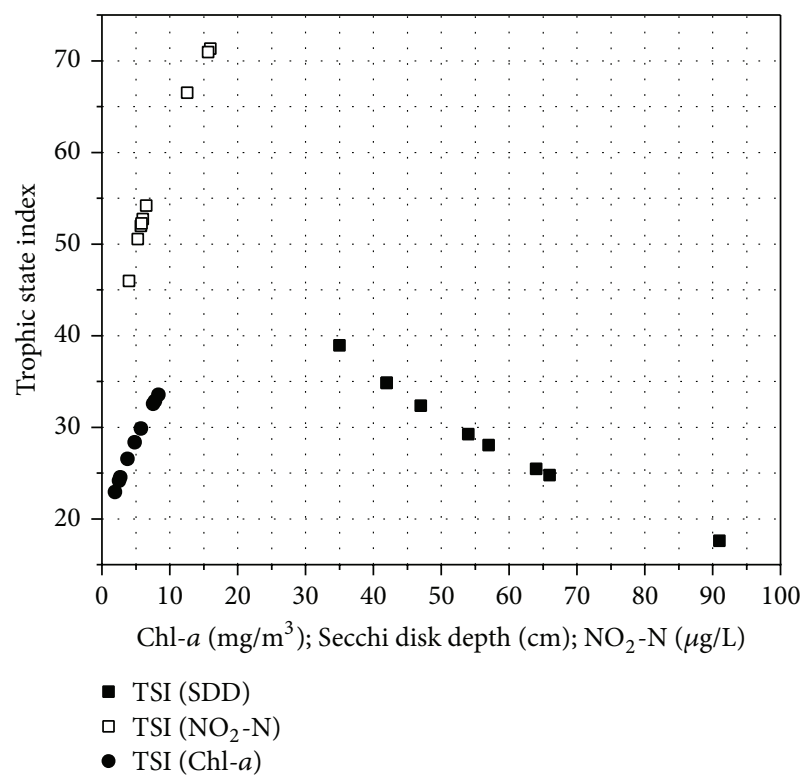

FIGURE 5: TSI validated/computed using observed values of Chl- $a$, $\mathrm{NO}_{2}-\mathrm{N}$, and SDD in Chilika lagoon. The displayed data for Chl- $a$, $\mathrm{NO}_{2}-\mathrm{N}$, and SDD are mean values of each at select locations in the lagoon during monsoon, postmonsoon, and summer periods.

addressed in previous studies. Yang et al. [2] reported TSI values ranging between 0 and 100 for Chl- $a$ concentrations between 17.05 and $264.54 \mu \mathrm{g} \mathrm{L}^{-1}$ and SDD between 12 and $257 \mathrm{~cm}$ compared to the ones in this paper (Table 1). Obviously, previous studies either lack the ability to cover a large range of Chl- $a$ or do not consider a nitrogen-based TSI.

4.5. Spatial and Temporal Variability within the Lagoon. Having discussed the three models, it is now imperative to advert to the spatial and temporal variability of Chl$a, \mathrm{NO}_{2}-\mathrm{N}$, and SDD within the lagoon. This is important for examination of computed TSI for different seasons and locations in the lagoon to assist in relevant management plans. The lagoon divides into three sectors spatially, that is, northern, southern, and central sectors, and temporally the lagoon experiences three different seasons during a year, that is, monsoon (July-October), postmonsoon (NovemberMarch), and summer (April-June). The mean Chl- $a$ concentration is highest $\left(8.33 \mathrm{mg} \mathrm{m}^{-3}\right)$ in the central sector during summer. The mean $\mathrm{NO}_{2}-\mathrm{N}$ concentration is highest $\left(15.98 \mu \mathrm{g} \mathrm{L}^{-1}\right)$ in the central sector during monsoon. The SDD is generally the lowest in the northern sector in any given season; that is, the water is clearer in the southern sector in all seasons. The proposed TSI accounts for the expected concentrations of Chl- $a$ and $\mathrm{NO}_{2}-\mathrm{N}$ and the SDD for any season covering all sectors of the lagoon.

\section{Conclusions}

This study offers new Chl- $a, \mathrm{NO}_{2}-\mathrm{N}$, and SDD based TSI expressions for the estimation of status of eutrophication in a lagoon system analogous to Carlson's index. Nitrogen being 
TABLE 4: TSI and corresponding values of Chl- $a, \mathrm{NO}_{2}-\mathrm{N}$, and SDD computed using Model C. It is noticeable that this model covers large ranges of $\mathrm{NO}_{2}-\mathrm{N}$ between 0.13 and $61.99 \mu \mathrm{g} \mathrm{L}-1$ and Chl- $a$ between 1.00 and $322.18 \mathrm{mg} \mathrm{m}^{-3}$. Model C shows significant improvement over Model A and Model B.

\begin{tabular}{lccc}
\hline TSI & SDD computed $(\mathrm{cm})$ & $\mathrm{NO}_{2}-\mathrm{N}_{\text {computed }}\left(\mu \mathrm{g} \mathrm{L}^{-1}\right)$ & ${\text { Chl- } a \text { computed }\left(\mathrm{mg} \mathrm{m}^{-3}\right)}$ \\
\hline 0 & 200 & - & - \\
10 & 128 & - & 1.00 \\
20 & 82 & 0.13 & 6.19 \\
30 & 52 & 1.13 & 14.31 \\
40 & 33 & 2.69 & 27.01 \\
50 & 21 & 5.14 & 46.89 \\
60 & 14 & 8.97 & 78.01 \\
70 & 9 & 14.96 & 126.70 \\
80 & 6 & 24.34 & 202.91 \\
90 & 4 & 39.02 & 322.18 \\
100 & 2 & 61.99 & \\
\hline
\end{tabular}

the fourth most abundant element found in the organisms is suitable for computing TSI of the lagoon. Nitrite is preferable because it decreases the fluorescence affecting the underwater photosynthesis and thereby controls primary productivity of Chilika lagoon. Nitrite is short-lived and readily converts into nitrate that does not affect fluorescence/photosynthesis [19]. $\mathrm{NO}_{2}-\mathrm{N}$ is preferable to TP because of its close relationship with other trophic state criteria such as Chl- $a$ and SDD. One can compute TSI using Chl- $a, \mathrm{NO}_{2}-\mathrm{N}$, and SDD; each of which alone is capable of providing an estimate of trophic status of the lagoon. The three parameters account for the biological, chemical, and physical characteristics of the lagoon. It will be possible to estimate the TSI of freshwater and brackish water lagoons and other water bodies using the new expressions taking into consideration the spatial and temporal variability in the dataset. TSI (SDD) provides first-hand information about the trophic state of the lagoon. Depending on the requirement and data availability, one can use alternative TSI (Chl- $a)$ and TSI $\left(\mathrm{NO}_{2}-\mathrm{N}\right)$ to account for the biological and chemical contributions to eutrophication status. The estimated TSI can account for Chl- $a$ and $\mathrm{NO}_{2}-\mathrm{N}$ up to $322.18 \mathrm{mg} \mathrm{m}^{-3}$ and $61.99 \mu \mathrm{g} \mathrm{L}^{-1}$, respectively. The TSI, based on these three parameters, serves as a complimentary index to assess nitrite levels and thereby primary productivity and as a predictive tool for lagoon management and prior to conducting field programs to monitor the health of a lagoon.

\section{Conflict of Interests}

The author declares that there is no conflict of interests regarding the publication of this paper.

\section{Acknowledgments}

The author is thankful to Dr. Shailesh R. Nayak of Space Applications Centre (Indian Space Research Organization) (now at Ministry of Earth Sciences, Government of India, New Delhi), Ahmedabad, India, for funding, support, and necessary data. Thanks are also due to the personnel from
Regional Research Laboratory, Bhubaneswar, India for executing the field campaigns and support.

\section{References}

[1] R. E. Carlson, “A trophic state index for lakes," Limnology and Oceanography, vol. 22, no. 2, pp. 361-369, 1977.

[2] J. Yang, X. Yu, L. Liu, W. Zhang, and P. Guo, "Algae community and trophic state of subtropical reservoirs in southeast Fujian, China," Environmental Science and Pollution Research, vol. 19, no. 5, pp. 1432-1442, 2012.

[3] R. A. Osgood, "Using differences among Carlson's trophic state index values in regional water quality assessment," Journal of the American Water Resources Association, vol. 18, no. 1, pp. 67-74, 1982.

[4] S. O’Boyle, G. McDermott, T. Noklegaard, and R. Wilkes, "A simple index of trophic status in estuaries and coastal bays based on measurements of $\mathrm{pH}$ and dissolved oxygen," Estuaries and Coasts, vol. 36, no. 1, pp. 158-173, 2013.

[5] G. Chalar, R. Arocena, J. P. Pacheco, and D. Fabián, “Trophic assessment of streams in Uruguay: a Trophic State Index for Benthic Invertebrates (TSI-BI)," Ecological Indicators, vol. 11, no. 2, pp. 362-369, 2011.

[6] R. A. Vollenweider, F. Giovanardi, G. Montanari, and A. Rinaldi, "Characterization of the trophic conditions of marine coastal waters with special reference to the NW Adriatic Sea: proposal for a trophic scale, turbidity and generalized water quality index," Environmetrics, vol. 9, no. 3, pp. 329-357, 1998.

[7] J. Padisák, G. Borics, I. Grigorszky, and É. Soróczki-Pintér, "Use of phytoplankton assemblages for monitoring ecological status of lakes within the water framework directive: the assemblage index," Hydrobiologia, vol. 553, no. 1, pp. 1-14, 2006.

[8] OSPAR Commission, OSPAR Integrated Report 2003 on the Eutrophication Status of the OSPAR Maritime Area Based Upon the First Application of the Comprehensive Procedure, OSPAR Commission, London, UK, 2003, http://www.ospar.org/documents/dbase/publications/p00189/ p00189_eutrophication\%20status\%20report\%202003.pdf.

[9] S. B. Bricker, J. G. Ferreira, and T. Simas, "An integrated methodology for assessment of estuarine trophic status," Ecological Modelling, vol. 169, no. 1, pp. 39-60, 2003. 
[10] C. T. Wezernak, F. J. Tanis, and C. A. Bajza, "Trophic state analysis of inland lakes," Remote Sensing of Environment, vol. 5, no. 2, pp. 147-165, 1976.

[11] S. Thiemann and H. Kaufmann, "Determination of chlorophyll content and trophic state of lakes using field spectrometer and IRS-1C satellite data in the Mecklenburg Lake District, Germany," Remote Sensing of Environment, vol. 73, no. 2, pp. 227-235, 2000.

[12] W. W. Walker Jr., "Use of hypolimnetic oxygen depletion rate as a trophic state index for lakes," Water Resources Research, vol. 15, no. 6, pp. 1463-1470, 1979.

[13] C. R. Kratzer and P. L. Brezonik, "A Carlson-type trophic state index for nitrogen in Florida lakes," Journal of the American Water Resources Association, vol. 17, no. 4, pp. 713-715, 1981.

[14] U. S. Panda, P. K. Mohanty, and R. N. Samal, "Impact of tidal inlet and its geomorphological changes on lagoon environment: a numerical model study," Estuarine, Coastal and Shelf Science, vol. 116, pp. 29-40, 2012.

[15] S. Pattanaik, "Conservation of environment and protection of marginalized fishing communities of lake Chilika in Orissa, India," Journal of Human Ecology, vol. 22, no. 4, pp. 291-302, 2007.

[16] A. S. Rajawat, M. Gupta, B. C. Acharya, and S. Nayak, "Impact of new mouth opening on morphology and water quality of the Chilika Lagoon - a study based on Resourcesat-1 LISS-III and AWiFS and IRS-1D LISS-III data," International Journal of Remote Sensing, vol. 28, no. 5, pp. 905-923, 2007.

[17] J. D. Strickland and T. R. Parsons, A Practical Handbook of Seawater Analysis, Bulletin 167, Fisheries Research Board of Canada, 1972.

[18] S. Brahma, U. C. Panda, K. Bhatta, and B. K. Sahu, "Spatial variation in hydrological characteristics of Chilika- a coastal lagoon of India," Indian Journal of Science and Technology, vol. 1, no. 4, pp. 1-7, 2008.

[19] E. Kessler and W. G. Zumft, "Effect of nitrite and nitrate on chlorophyll fluorescence in green algae," Planta, vol. 111, no. 1, pp. 41-46, 1973.

[20] S. Panigrahi, B. C. Acharya, R. C. Panigrahy, B. K. Nayak, K. Banarjee, and S. K. Sarkar, "Anthropogenic impact on water quality of Chilika lagoon RAMSAR site: a statistical approach," Wetlands Ecology and Management, vol. 15, no. 2, pp. 113-126, 2007. 

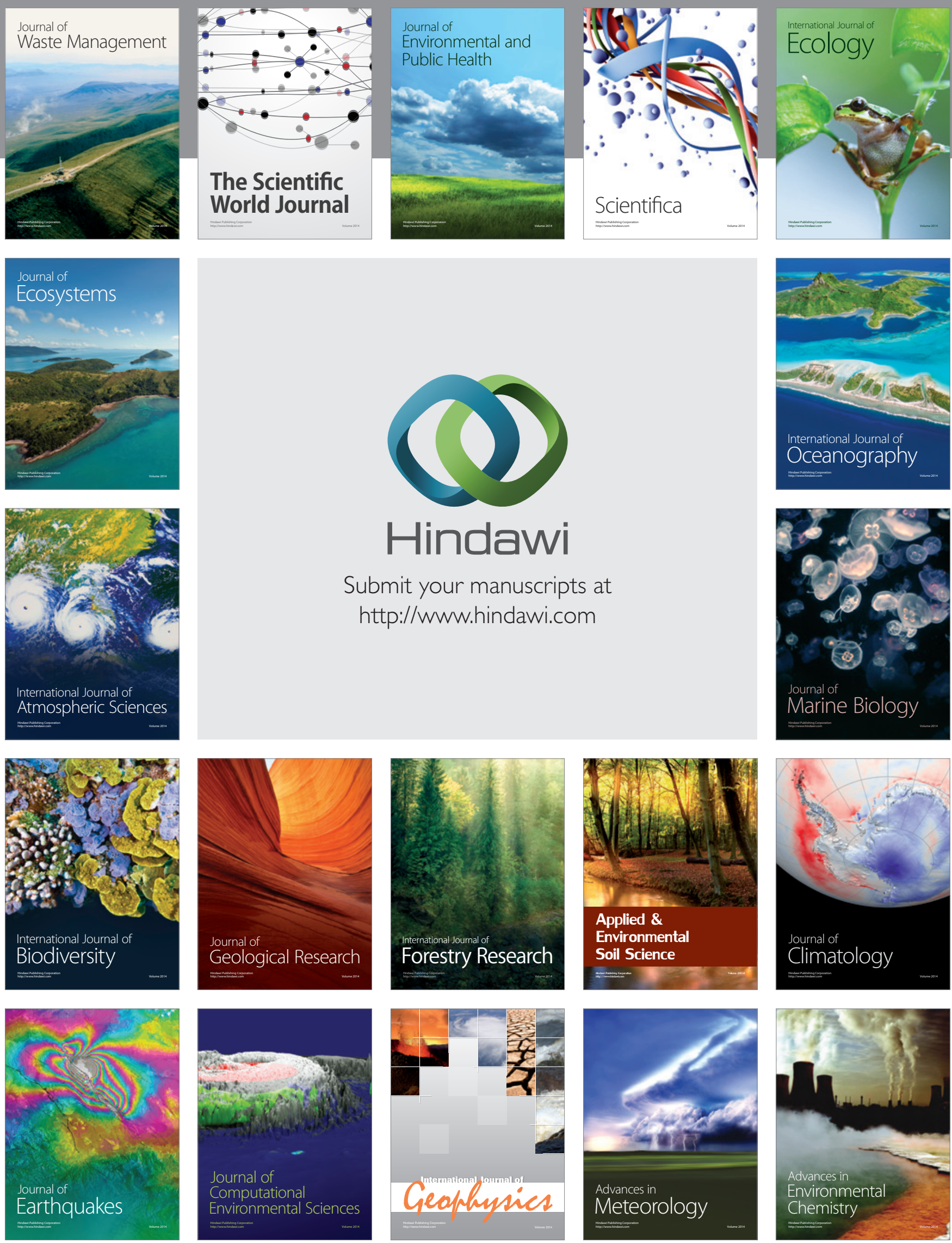